\title{
The Mathematical Field Trip
}

\author{
Cahit Shacham \\ Dept. of Mathematics, Academic Gordon College \\ Chernichovsky 73, Haifa Israel \\ Tel: 972-524213630Ｅ-mail: cahit@netvision.net.il
}

Ilana Levenberg

Dept. of Mathematics, Academic Gordon College

Chernichovsky 73, Haifa Israel

Tel: 972-505654889 E-mail: dveer@netvision.net.il

Accepted: Oct 13, 2013 Published: Oct 27, 2013

Doi:10.5296/ijld.v3i5.3951 URL: http://dx.doi.org/10.5296/ijld.v3i5.3951

\begin{abstract}
The Enrichment Center for Gifted and Highly Talented Children is based at the Gordon Academic College of Education in Haifa and attracts fourth to sixth grade children from 30 different schools. The center offers a wide variety of workshops including a workshop on Mathematical thought. One of the activities of the mathematical thought workshop is a trip in the college's neighborhood. The trip offers a diversity of activities in the field of mathematics teaching, and exposure to the fields of geography, history and science, in a manner that is different from what is generally offered in a typical classroom lesson.

Gifted and talented children are known as curious and creative and therefore the trip's activities provide a challenging and unusual learning environment away from the classroom. The trips have proven to be highly motivating for investigation and questioning among the students.
\end{abstract}

Keywords: China insurance industry, Foreign fund, Challenge

\section{Introduction}

Most studies dealing with mathematical education deal with the difficulties encountered by students in learning mathematics. One of the main reasons for these difficulties is the gap between the level of instruction and the student's capabilities and understanding of mathematical concepts (Patkin \& Levenberg, 1994). In addition the unique characteristics of mathematics as abstract and hard to understand cause difficulties and obstacles to the students. Therefore it is recommended that multi-disciplinary activities should be integrated into the mathematical instruction using examples which activate the imagination while acquiring mathematical knowledge. In this manner, the students will have a more significant and better understanding of mathematical concepts (Hershkowitz, \&Vinner,1984)

In the Standards for School Mathematics which has been published over the years by the National Council of Mathematical Teachers many suggestions have been made to improve mathematical instruction in the schools and to adjust mathematical instruction to the technological needs of the 21st century (NCTM, 2000). These suggestions are based on the assumption that the field of mathematics includes content matter from a wide variety of subjects that are essential for students learning in a technological society. They recommend using auxiliary materials in mathematical 
instruction which aid the students by emphasizing provision and development of cognitive skills and understanding mathematical concepts. The ultimate goal is to develop mathematical literacy; to read, speak and write mathematics. These recommendations provide the foundation of the mathematical field trip.

\section{The Mathematical Field Trip}

\subsection{Pedagogical and Didactics Goals}

The trip in the college's neighborhood covers a number of sites and combines historical and geographical perspectives along with mathematics. Several goals have been realized during the mathematics tour:

- Acquiring knowledge through experience and curiosity.

- Changing the learning environment into an open and inviting dynamic environment outside of the school classroom.

-Developing the student's ability to cope with relevant problems, applying tools from diverse fields.

-Showing the relationship between mathematics and areas such as: history, geography, physics and more.

-Reducing the anxiety of learning Mathematics.

The mathematical field trip takes place within the vicinity of the Gordon Academic College of Education in Haifa, Israel.

The field trip includes the following sites: the Carmelite monastery, the lighthouse, the cable car, and the observation site overlooking Haifa Bay.

2.2 The preparation of the Mathematical Filed Trip was done in the following manner:

a) Possible sites providing a source for mathematical activity were chosen

b) The chosen sites were photographed

c) The historical and geographical backgrounds of the chosen sites were researched

d) The level of suitability of the activities was compared to the level of mathematics taught at the elementary school level.

e) A wide variety of mathematical activities were prepared and just a selected few were chosen for the mathematical field trip.

f) The field trip was tested by college students specializing in mathematics.

The mathematical field trip is unique because it integrates mathematical principles taught in elementary school and applies them to the immediate environment. The subjects involved in the trip include: measurements, the world of whole and rational numbers, geometric forms and bodies, symmetry, percentage, fractions, and more.

\subsection{Target Population and Length of Field Trip}

The target population in this study includes the children that attend the Enrichment Center for Gifted and Highly Talented Children based at the Gordon Academic College of Education in Haifa. The children who are in the fourth to sixth grade level come from 30 different schools within the Haifa Municipality District. Although this field trip was done with gifted and talented children, it is also applicable to all children of different scholastic levels. The field trip lasts 4 hours including summary and feedback.

\subsection{Required Mathematical Knowledge}

The students should be able to master the four basic mathematical operations (adding, subtracting, multiplication and division) and to apply them to whole numbers, simple fractions and decimals. They should have basic knowledge in the following concepts: percentage, average and graphic coordinate systems. They should also be able to use calculators.

Mathematical missions are performed at each site using the following guides and tools: maps, calculators, measuring tape, and writing utensils. 


\section{Description of the Activities}

During the mathematical field trip students perform mathematical investigations outside of the classroom environment in which they learn more about the immediate vicinity of the Gordon Academic College. Some of the sites such as the Carmelite Monastery and the lighthouse are historical and archeological. Some of the sites are modern such as the cable car and the modern pavement of the sidewalk leading to the monastery and the lighthouse. The field trip integrates the historical and geographical aspects of each site together with mathematical activities relevant to the site. During the field trip the students are exposed to mathematical applications within a wide variety of subject matter. These topics are usually taught in the classroom in an abstract manner without any relationship to reality and without any representation of examples from the outside environment.

The actual sites involved in this field trip provide us with a very wide variety of activities. For example; the students learn about the history of the Carmelites and the unique architecture of the Carmelite Monastery. The mosaic pavement at the entrance to the monastery provides investigative activities in geometry, which is usually performed in the classroom with only chalk and a blackboard. Moreover, the field trip provides opportunities to perform activities dealing with contemporary issues such as checking the traffic level of motor vehicles within the vicinity of the college or the total cost of a trip on the cable car for the entire class. These activities integrate practical mathematics with physics and economics.

\section{Conclusion}

After several years of application within the framework of The Enrichment Center for Gifted and Highly Talented Children at the Gordon Academic College of Education in Haifa, the goals of the mathematical field trip have been achieved. The field trip suggests a wide variety of mathematical activities and exposure to subject matter outside of the classroom. It enables interesting and non conventional mathematical activities to the student at the elementary school level. The children learn math through experience and curiosity and develop the ability to cope with relevant problems. In addition the students learn more about the relationship between math and other fields of learning such as: biology, history, geography, physics, economics and other disciplines. Moreover, the mathematical field trip develops mathematical activity in a different and challenging learning atmosphere.

\section{References}

Hershkowitz, R. \& Vinner, S. (1984). Children's concept in elementary geometry - a reflection of teacher's concepts? Proceedings of the Eighth International Conference for the P. M. E. pp. 63-70

National Council of Teachers of Mathematics (2000). Principles and standards for school mathematics. Reston, VA: NCTM.

Patkin, D. \& Levenberg, I. (1994). A look at geometry in nature and around us. Another way to train preservice teachers to teach geometry. A paper presented in PME 18 Lisbon, Portugal.

This article is an open-access article distributed under the terms and conditions of the Creative Commons Attribution license (http://creativecommons.org/licenses/by/3.0/). 